\title{
Czy wszyscy muszą być kreatywni?
}

DOI: $10.47050 / 65591876.32-48$

Aldona Andrzejczak

Celem rozdziału jest krytyczna refleksja nad powszechnością wymagania kreatywności z perspektywy szkoły i rynku pracy. Punkt wyjścia stanowią rozważania dotyczące istoty kreatywności oraz możliwości jej pomiaru. Następnie zwrócono uwagę na kluczową rolę szkoły w odkrywaniu i rozwijaniu kreatywności uczniów ze szczególnym uwzględnieniem znaczenia dywergencyjnego stylu uczenia się zdefiniowanego przez Davida Kolba. W trzeciej części rozdziału przeanalizowano możliwość oceny i pomiaru w warunkach przedsiębiorstwa poziomu kreatywności pracowników i kandydatów do pracy. Mimo wykazania przydatności podejścia kompetencyjnego do diagnozy poziomu kreatywności pracowników w przedsiębiorstwie, wskazano jednak na nieadekwatność stosowania tego wymogu wobec wszystkich kandydatów do pracy.

\section{Słowa kluczowe:}

kreatywność

uczenie się dywergencyjne i konwergencyjne

kompetencje

pomiar kompetencji

wymogi stanowiska pracy 


\section{Does everyone have to be creative?}

DOI: 10.47050/65591876.32-48

Aldona Andrzejczak

The aim of the article is a critical reflection on the common requirement of the creativity from the point of view of the school and the labor market. The starting point are considerations regarding the nature of creativity and the possibilities of its measurement. In the following part, attention was paid to the key role of the school in the discovery and development of students' creativity, focusing on the importance of the divergent learning style defined by David Kolb. The third part of the article deals with the possibility of assessing and measuring the level of creativity of employees and job candidates in the company. However, despite demonstrating the suitability of the competence approach to diagnosing the level of creativity of employees in the company, the inadequacy of applying this requirement to all candidates for work was indicated.

\section{Keywords:}

creativity

divergent and convergent learning

competences

measurement of competences

job requirements 


\section{Wprowadzenie}

Kreatywność stała się w ostatnich latach terminem bardzo popularnym, wymienianym jako jedna z najważniejszych kompetencji XXI w. Szybko zmieniający się współczesny świat stawia wymagania, którym często efektywnie sprostać może tylko osoba myśląca w sposób nietypowy, oryginalny, nowatorski, wykraczający poza schematy. Teresa Parczewska i Iwona Zwierzchowska wyliczają, że kreatywność stanowi klucz do postępu i rozwoju, źródło innowacji, ulepszeń i odkryć w różnych sferach życia społecznego, kulturowego i ekonomicznego, wpływa na sposób działania jednostki nie tylko w sytuacjach problemowych, lecz także w zwyczajnych, codziennych sytuacjach bycia w świecie (Parczewska, Zwierzchowska 2017, s. 34). Dlatego na każdym kroku słyszymy, jak ważną i potrzebną kompetencją jest kreatywność rozumiana jako zdolność do tworzenia nowych, lepszych rozwiązań napotykanych problemów. Bycie kreatywnym przynosi zarówno jednostce, jak i jej otoczeniu wiele korzyści. Ale co jeśli kreatywny pracownik stworzy rozwiązanie, które zagraża otoczeniu albo którego otoczenie nie akceptuje? Czy nadal jego kreatywność jest postrzegana jako coś pozytywnego? Czy rzeczywiście, jak twierdzi Edward de Bono, kreatywność jest umiejętnością i każdy może się jej nauczyć? Dlatego w tym miejscu warto przyjrzeć się krytycznie, na ile możliwe jest powszechne rozwijanie kreatywności, a na ile mamy do czynienia z modą na przypisywanie kreatywności nadmiernego znaczenia, zwłaszcza że możliwości precyzyjnego jej zdefiniowania i pomiaru są ograniczone i dyskusyjne. W szczególności należałoby zweryfikować zasadność coraz powszechniejszego wymagania kreatywności od kandydatów do pracy, przy ograniczonych możliwościach jej pomiaru przez pracodawców.

Pytanie postawione $w$ tytule wynika po części także $z$ tego, że specjaliści dzielą się na tych, którzy zakładają, że każdy jest kreatywny i może dalej swoją kreatywność rozwijać, oraz tych, którzy raczej eksponują różnice między indywidualnym potencjałem do rozwijania kreatywności. W konsekwencji prowadzi to do podziału na osoby bardziej i mniej zdolne do kreatywności. Przy próbie odpowiedzi na postawione w tytule pytanie zostanie rozważona perspektywa edukacji, tzn. szkoły i nauczycieli, oraz rynku pracy, w szczególności pracodawców.

Ze względu na ograniczone ramy niniejszego opracowania kwestia definiowania kreatywności i sporu dotyczącego sposobu jej postrze- 
gania zostanie potraktowana bardzo ogólnie. W tym rozdziale kreatywność będzie analizowana nie tyle jako zbiór cech wyróżniających osobę kreatywną, ale jako zachowanie osoby cechującej się większą lub mniejszą kreatywnością.

\section{Postrzeganie i pomiar kreatywności}

Potocznie kreatywność jest często utożsamiana z twórczością. Jednak i w tej kwestii naukowcy są podzieleni. Dodatkowo niektórzy jako warunek kreatywności traktują powstanie dzieła (Fazlagić 2015, s. 19). Różnice występują także w sposobie wiązania kreatywności z człowiekiem. Jedni uważają, że kreatywność stanowi cechę człowieka, która podlega pomiarowi (Nęcka 2001). Inni kreatywność traktują jako rezultat oddziaływania wzajemnie ze sobą powiązanych cech (Karwowski 2010). Dla jeszcze innych kreatywność jest postawą i działaniem człowieka (Szmidt 2010).

Wiązanie kreatywności z twórczością zdecydowanie zawężałoby grono osób kreatywnych, gdyż twórcy określonych wytworów są zazwyczaj grupą elitarną, bardziej lub mniej wyjątkową, a rezultat ich twórczości powinien być oryginalny i nowatorski. Jak zauważa Krzysztof Szmidt, w nauce nie ma zresztą jednoznacznej definicji twórczości, gdyż rozumienie tego terminu ewoluowało w czasie i było różnie ujmowane, w zależności od przyjmowanej perspektywy badawczej (Szmidt 2013). Rozważano cechy osób twórczych, analizowano proces twórczy, badano uwarunkowania twórczości. Zauważono, że twórczość niekoniecznie łączy się z powstaniem dzieła, natomiast można mówić o twórczym myśleniu i działaniu, twórczych operacjach umysłowych. Można uznać, że każdy twórca jest kreatywny, ale nie każda osoba kreatywna jest twórcą. Tu pojawia się miejsce na określenie kreatywności. Podsumowując dotychczasowe rozważania, można przyjąć, że kreatywność stanowi proces umysłowy przejawiający się w zachowaniu człowieka, polegający na tworzeniu nowych idei, koncepcji lub nowych skojarzeń dzięki myśleniu nieschematycznemu, wymyślaniu nowych pomysłów i sposobów działania oraz zdolności do ich wdrażania. Myślenie kreatywne to myślenie prowadzące do uzyskania oryginalnych rozwiązań, które mogą być zastosowane. Tak więc kreatywność to zdolność do niestereotypowego myślenia i działania, która umożliwia elastyczne reagowanie na potrzeby środowiska i nowatorskie podejście do realizowanych zadań. 
Dla dalszych rozważań istotne znaczenie ma praktyczny sposób ujmowania kreatywności. W jakim stopniu jest to cecha intelektualna osoby, a w jakim cecha charakteru podlegająca kształtowaniu i wpływowi otoczenia. A może jest to wypadkowa różnych predyspozycji człowieka? Dla pełnego rozumienia pojęcia kreatywności zasadne wydaje się przywołanie teorii prezentowanej przez Roberta J. Sternberga (2006 za: Parczewska, Zwierzchowska 2017, s. 24), który wskazywał na sześć powiązanych ze sobą źródeł kreatywności. Są nimi:

$\rightarrow$ zdolności intelektualne,

$\rightarrow$ wiedza,

$\rightarrow$ style myślenia,

$\rightarrow$ osobowość,

$\rightarrow$ motywacja,

$\rightarrow$ otoczenie.

W polskiej literaturze (Karwowski 2010, s. 14) panuje pogląd, że kreatywność tworzą trzy wzajemnie powiązane cechy, tj.:

$\rightarrow$ zdolności twórcze,

$\rightarrow$ otwartość,

$\rightarrow$ niezależność.

Na podstawie różnych kombinacji natężenia powyższych cech Maciej Karwowski $(2010$, s. 16) stworzył osiem różnych konfiguracji cech, które można interpretować jako swoistą próbę kategoryzacji kreatywności:

$\rightarrow$ niska otwartość, niska niezależność, niskie zdolności twórcze odtwórczość, imitacyjność;

$\rightarrow$ niska otwartość, niska niezależność, wysokie zdolności twórcze - adaptacja, kreatywność zduszona;

$\rightarrow$ niska otwartość, wysoka niezależność, wysokie zdolności twórcze - kreatywność sztywna i buntownicza;

$\rightarrow$ niska otwartość, wysoka niezależność, niskie zdolności twórcze - destrukcyjny bunt;

$\rightarrow$ wysoka otwartość, wysoka niezależność, niskie zdolności twórcze - twórcza osobowość, twórczość samorealizująca się, pierwotna kreatywność bez szans na twórczość;

$\rightarrow$ wysoka otwartość, niska niezależność, niskie zdolności twórcze - wycofana ciekawość; 
$\rightarrow$ wysoka otwartość, niska niezależność, wysokie zdolności twórcze - kreatywność podporządkowana;

$\rightarrow$ wysoka otwartość, wysoka niezależność, wysokie zdolności twórcze - pełna kreatywność.

Powyższe podejście do kreatywności wydaje się szczególnie inspirujące. Dzięki precyzyjnemu określeniu stopnia otwartości i niezależności poszczególnych osób oraz przejawiania przez nie zdolności twórczych pozwala bowiem mierzyć poziom i charakter ich kreatywności.

\section{Rola szkoły w rozwijaniu kreatywności}

Skoro ludzie różnią się między sobą pod względem natężenia cech związanych z kreatywnością, to warto zaznaczyć, że właśnie w szkole występują idealne warunki, aby kreatywność konkretnych uczniów odkrywać i rozwijać. Jednak rozwijanie kreatywności wymaga szczególnego podejścia do realizacji podstawowego zadania szkoły, jakim jest przygotowanie uczniów do życia w otaczającym świecie. Jak pokazuje raport z badań zamówionych przez Ministerstwo Przedsiębiorczości i Technologii, polska szkoła nie rozwija kreatywności uczniów, czemu na przeszkodzie stoi głównie powierzchowne uczenie się, polegające na pamięciowym przyswajaniu dużych partii materiału, podział na przedmioty, faworyzowanie w szkole uczniów zdyscyplinowanych i potulnych oraz zabijanie spontaniczności w działaniu (Fazlagić 2018a).

Ogólnie bariery utrudniające w szkole rozwijanie kreatywności uczniów można podzielić na związane z tradycyjnym postrzeganiem roli szkoły oraz trudności realizacyjne (czas, kompetencje i motywacja nauczycieli, warunki materialne w szkole). Warto jednak zauważyć, że szkoły, a zwłaszcza niektórzy nauczyciele, w ostatnich dekadach podejmują też wysiłki zmierzające do tworzenia klimatu dla rozwoju kreatywności uczniów. Wydaje się, że rozwiązanie zasygnalizowanego problemu w całej jego złożoności lepiej jednak pozostawić specjalistom, tzn. władzom oświatowym i nauczycielom posiadającym w tym zakresie znaczne osiągnięcia. Przydatne mogą okazać się rekomendacje przedstawione w raporcie Szkoła dla innowatora. Kształtowanie kompetencji proinnowacyjnych.

Związek kreatywności ze sposobem uczenia się i nauczania jest oczywisty ze względu na sposób myślenia. Występuje wiele sposobów 
podejścia do podziału rodzajów myślenia. Warto odwołać się w tym miejscu do wprowadzonego przez Joya Paula Guilforda w latach 60. $X X$ w. podziału na myślenie konwergencyjne i dywergencyjne. Myślenie konwergencyjne (inaczej zbieżne) cechuje się poszukiwaniem jednego właściwego rozwiązania, gdyż każdy problem ma swoją przyczynę. Myślenie konwergencyjne hamuje zatem kreatywność. Z kolei myślenie dywergencyjne (inaczej rozbieżne) pojawia się w przypadku istnienia wielu możliwych rozwiązań. Oznacza więc tworzenie kilku rozwiązań tego samego problemu i wyjście poza istniejące schematy i wzorce rozumowania. Z punktu widzenia kreatywności ma ono zatem fundamentalne znaczenie. Nietrudno jednak skonstatować, że o ile małe dzieci mają skłonność do myślenia dywergencyjnego, to w szkole wymagania programowe i po części testowy system sprawdzania osiągnięć uczniów sprzyjają utrwalaniu myślenia konwergencyjnego (Szmidt 2013).

W późniejszych etapach edukacji, kiedy uczeń staje się bardziej samodzielny, istotne znaczenie ma wypracowany na wcześniejszych etapach edukacji styl uczenia się. Przydatny zarówno dla nauczycieli, jak i dla uczniów jest tu cykl uczenia się opracowany przez amerykańskiego psychologa Davida Kolba (1984). Cykl ten obejmuje cztery etapy:

$\rightarrow$ konkretne przeżycie,

$\rightarrow$ refleksyjną obserwację,

$\rightarrow$ abstrakcyjne uogólnianie,

$\rightarrow$ aktywne eksperymentowanie.

Badania nad procesem uczenia się i występującymi kombinacjami sposobów uczenia się pozwoliły na wyodrębnienie czterech stylów uczenia się:

$\rightarrow$ Styl konwergencyjny odznacza się wysoką umiejętnością praktycznego stosowania wiedzy teoretycznej. Wymaga więc posiadania zdolności do abstrakcyjnego myślenia i aktywnego eksperymentowania.

$\rightarrow$ Styl dywergencyjny opiera się bardziej na wykorzystaniu konkretnego przeżycia i refleksyjnej obserwacji. Wymaga wyobraźni, postrzegania danego problemu z różnych perspektyw, zaangażowania emocjonalnego. 
$\rightarrow$ Styl asymilacyjny opiera się na dominacji abstrakcyjnego uogólniania i refleksyjnej obserwacji. Styl ten prowadzi najczęściej do logicznego i precyzyjnego porządkowania zagadnień oraz tworzenia modeli i teorii.

$\rightarrow$ Styl akomodacyjny, w którym dominuje aktywne eksperymentowanie i konkretne przeżycie, cechuje się zaangażowaniem we wdrażanie planów i poszukiwanie nowych doświadczeń.

Ludzie różnią się pod względem dominującego stylu uczenia się, ale zgodnie z cyklem uczenia się w praktyce w różny sposób kompensują swoje słabsze strony, np. ucząc się w grupie albo podejmując działania zmierzające do zredukowania własnych ograniczeń. Natomiast osoby charakteryzujące się dywergencyjnym stylem uczenia się w praktyce będą wykazywały się wyższą kreatywnością. Brak przewagi tego stylu w grupach menedżerów wskazuje jednak, że nie musi to stanowić przeszkody w karierze zawodowej.

Rodzi się pytanie, jak można w szkole tworzyć warunki sprzyjające rozwijaniu dywergencyjnego stylu uczenia się. Przydatne może się tu okazać poznanie ograniczeń w rozwoju kreatywnego myślenia. Krzysztof Szmidt (2010) zwrócił uwagę na występowanie barier zarówno poznawczych, jak i emocjonalno-motywacyjnych w rozwoju kreatywności (tabela 1). Niektóre z nich wydają się silnie powiązane z cechami osobowymi ucznia, ale większość można ograniczać poprzez odpowiednie organizowanie procesu uczenia się.

Tabela 1. Główne bariery poznawcze i emocjonalno-motywacyjne w rozwoju kreatywności

\begin{tabular}{l|l}
\multicolumn{1}{c|}{ BARIERY POZNAWCZE } & \multicolumn{1}{c}{ BARIERY EMOCJONALNO-MOTYWACYJNE } \\
\hline$\rightarrow$ mała spostrzegawczość & $\rightarrow$ lęk przed nieznanym \\
$\rightarrow$ sztywność myślenia & $\rightarrow$ niechęć do nowości \\
$\rightarrow$ brak otwartości na nowe treści & $\rightarrow$ brak tolerancji dla wieloznaczności \\
$\rightarrow$ przedwczesne zamykanie sytuacji & $\rightarrow$ brak wytrwałości i umiejętności odraczania \\
problemowej & gratyfikacji (uzyskania nagród) \\
$\rightarrow$ ślepota na rzeczy do zrobienia (naprawienia, & $\rightarrow$ lęk przed oceną i ośmieszeniem się \\
modyfikacji) & $\rightarrow$ lęk przed ryzykiem \\
$\rightarrow$ dominacja wyobraźni odtwórczej & $\rightarrow$ przesadny konformizm i uleganie grupie \\
\hline
\end{tabular}

Źródło: Szmidt 2010, s. 22 
Można zauważyć, że podatne na oddziaływanie nauczyciela i szkoły wydają się bariery zarówno emocjonalno-motywacyjne, jak i - może w nieco mniejszym stopniu - poznawcze. Poprzez formy i metody pracy na lekcjach oraz na zajęciach pozalekcyjnych można próbować stopniowo je ograniczać lub eliminować. Warto przy tym zaznaczyć, że nie chodzi o wyróżnianie uczniów bardziej kreatywnych, ale o wytworzenie wśród wszystkich uczniów atmosfery wolnej od obaw przed ośmieszeniem oraz zachęcanie ich do ciekawości i odkrywania wielu możliwych rozwiązań, zgłaszania i rozwijania pomysłów oraz wyciągania wniosków, dzięki czemu uczniowie stopniowo zaadaptują się do bardziej kreatywnego rozwiązywania problemów.

\section{Kreatywność jako wymóg pracodawcy wobec pracowników}

W dzisiejszych czasach w różnych sytuacjach bardzo eksponuje się znaczenie i potrzebę kreatywności. Ma to swoje uzasadnienie w zmianie paradygmatu rozwoju, polegającej na przejściu do gospodarki opartej na wiedzy i innowacjach. Kwestia kreatywności stała się tak powszechne, że na wszelki wypadek większość pracodawców, formułując swoje wymagania wobec przyszłych pracowników, oczekuje od nich także kreatywności. W tym miejscu nasuwają się dwa zasadnicze pytania. Po pierwsze, czy pracodawcy posiadają narzędzia do oceny kreatywności? Skoro poważne problemy ze zdefiniowaniem kreatywności mają naukowcy, to jak sobie z tym wymogiem radzą pracodawcy? Drugie pytanie dotyczy adekwatności wymogu kreatywności do charakteru realizowanych zadań.

W odniesieniu do odpowiedzi na pierwsze pytanie: praktyka zarządzania zasobami ludzkimi w organizacjach podsuwa rozwiązanie polegające na zastosowaniu podejścia kompetencyjnego. Zgodnie z regułami sztuki proces pozyskiwania nowego pracownika rozpoczyna się od analizy obowiązków i przygotowania opisu stanowiska, na który składają się opis pracy i opis wymagań stanowiska, nazywany niekiedy profilem wymagań kompetencyjnych. Ograniczając się do najważniejszych elementów tego opisu, można wymienić m.in.: zadania realizowane na danym stanowisku, zależności i relacje służbowe z innymi stanowiskami, zakres odpowiedzialności za decyzje i wyniki oraz urządzenia i aparaturę wraz z oprogramowaniem. Informacje zawarte $w$ takim opisie służą do sprecyzowania, jaka wiedza, umiejęt- 
ności, motywacja, predyspozycje fizyczne, społeczne i psychiczne są potrzebne do efektywnego wykonywania pracy na danym stanowisku. Wymienione elementy są czynnikami warunkującymi sprawność zawodową pracownika. Jednak w firmach, w których nadal dominuje bardzo tradycyjne podejście do rekrutacji pracowników, uwagę zwraca się głównie na sformułowanie wymagań formalnych, tj. wykształcenie, określona liczba lat doświadczenia na podobnym stanowisku, ewentualnie konkretne certyfikaty potwierdzające określone kwalifikacje. Do nich najczęściej dopisuje się kilka wymagań dotyczących cech pożądanego kandydata. Jednak to nieprofesjonalne podejście do rekrutacji pracowników jest stopniowo zastępowane przez podejście oparte na profilach kompetencyjnych.

Pojęcie kompetencje wyparło wykorzystywane wcześniej kwalifikacje, będące przeważnie jedynie formalnym potwierdzeniem zaliczonych form edukacji szkolnej. Praktyczna przydatność kompetencji polega na tym, że nawiązują one do sposobu, w jaki zachowują się pracownicy w różnych sytuacjach zawodowych. Kompetencje mogą być więc traktowane jako miara wskazująca, w jakim stopniu pracownik w określonej sytuacji związanej z pracą wykorzystuje swoje zasoby intelektualne, emocjonalne, moralne. Kompetencje wskazują, jak w zachowaniach organizacyjnych przejawia się wewnętrzny potencjał pracownika, umożliwiający mu adaptację do wyzwań otoczenia i uczenie się. Pojęcie kompetencji doczekało się licznych definicji (Filipowicz 2016 , s. 44). Myślenie w kategoriach kompetencji zakłada, że człowiek dąży do wykorzystania swoich osobistych predyspozycji i zgromadzonego doświadczenia oraz nieustannie uczy się, jak zwiększać własną efektywność (Filipowicz 2016, s. 17). Przedmiotem dociekań badawczych jest więc zidentyfikowanie czynników, które kształtują kompetencje. Definiując je, uwzględnia się przykładowo wiedzę, umiejętności, uzdolnienia, style działania, osobowość, wyznawane zasady, zainteresowania i inne cechy, które używane i rozwijane w procesie pracy prowadzą do osiągania rezultatów zgodnych ze strategicznymi zamierzeniami przedsiębiorstwa (Rostkowski, Szczęsna 2004, s. 90). Trzeba podkreślić, że istotą zastosowania kompetencji w zarządzaniu zasobami ludzkimi jest podejście behawioralne do kompetencji, tzn. skoncentrowanie się na opisie zachowania potrzebnego do kompetentnego, właściwego wykonywania zadań. Kompetencje jako takie nie są obserwowalne, ale dzięki zachowaniu pracownika można 
wnioskować, na jakim poziomie daną kompetencję posiada. Dlatego z praktycznego punktu widzenia można przyjąć, że kompetencje to dyspozycje w zakresie wiedzy, umiejętności i postaw, pozwalające realizować zadania zawodowe na odpowiednim poziomie (Filipowicz 2016, s. 46). Podsumowując, podejście kompetencyjne (zarządzanie oparte na kompetencjach) może być praktycznym sposobem poradzenia sobie $z$ dylematem oceny kompetencji pracownika w zakresie kreatywności.

W polskiej literaturze Tadeusz Oleksyn (2006), charakteryzując najważniejsze kompetencje wymagane na rynku pracy, wymienił wśród nich kreatywność i innowacyjność. Podkreślił również, że nie są one tożsame, ale mogą być rozpatrywane łącznie. Kreatywność wiązał z twórczością, czyli tworzeniem czegoś nowego i oryginalnego, natomiast innowacyjność łączył z elementami zarówno twórczymi, jak i odtwórczymi, gdyż definiował ją jako wprowadzanie nowych lub niekoniecznie nowych rzeczy do praktyki organizacji (Oleksyn 2006, s. 59).

Zgodnie z zasadami kompetencja "kreatywność" powinna mieć swoją definicję, a następnie wymiary, tj. opisy zachowania pracownika zachowującego się kolejno: mało kreatywnie, bardziej kreatywnie, aż do bardzo kreatywnie - w zależności od przyjętej skali addytywnej lub rozwojowej. Jak bardzo jest to trudne, tzn. subiektywne, mało konkretne i sprawdzalne, działanie, niech posłuży przykład. Poniżej definicje kreatywności skonstruowane przez studentów drugiego roku studiów magisterskich na specjalności zarządzanie zasobami ludzkimi:

$\rightarrow$ Umiejętność twórczego myślenia, rozwiązywanie problemów w sposób twórczy i nietypowy, bogata wyobraźnia, ekspresyjność, oryginalność w działaniu, niezawodne rozwiązania.

$\rightarrow$ Umiejętność kreowania nowych rzeczy i pomysłów. Zdolność dzielenia się swoją wiedzą i pomysłami z innymi. Osoba mająca niestandardowe pomysły i rozwiązania, umiejąca współpracować z grupą.

$\rightarrow$ Umiejętność twórczego myślenia, nowatorskie podejście, otwartość na trendy i nowinki branżowe, propagowanie oryginalnych, nowych rozwiązań, odejście od tradycyjnego myślenia, abstrakcyjne myślenie. 
Definicje te są podobne i pokazują powiązanie z innymi kompetencjami, np. umiejętnością współpracy w grupie czy dzielenia się wiedzą. Definicje kreatywności stworzone przez studentów warto skonfrontować z definicją wypracowaną na potrzeby projektu badawczego, a następnie ocenioną przez 135 przedsiębiorców z Polski, Słowacji, Słowenii i Finlandii. Była ona następująca: „Kreatywność to zespół wiedzy, umiejętności i postaw praktycznego wykorzystania technik twórczego myślenia w celu tworzenia oryginalnych i użytecznych rozwiązań problemów, wypracowania nowych koncepcji lub nowych powiązań z istniejącymi już ideami i koncepcjami". W definicji tej wyodrębniono trzy zachowania: zdolność do tworzenia użytecznych rozwiązań, zdolność do twórczego myślenia i wypracowywania nowych koncepcji oraz zdolność do generowania oryginalnych pomysłów (Jędrzejczyk 2017, s. 17). Można zauważyć, że propozycje studentów są zbliżone do tych wypracowanych w gronie fachowców, co oznacza, że pracodawcy mogą definiować kreatywność w formie pożądanych zachowań.

Dużo ciekawsze jest jednak to, jak studenci zwymiarowali poszczególne poziomy posiadania kompetencji „kreatywność". Dla ułatwienia opisy zachowania zostały ujęte $w$ tabeli 2. Niezależnie od nasuwających się uwag szczegółowych i możliwości udoskonalenia propozycji zawartych w tabeli 2 (wypracowanych w krótkim czasie przez studentów na zajęciach), wynika z nich jasno, że na poziomie konkretnej organizacji jest możliwe zdefiniowanie i zwymiarowanie kompetencji kreatywności przy wykorzystaniu podejścia behawioralnego. Wymaga to pewnego wysiłku, czasu i fachowości, ale opisanie zachowań pracowników wskazujących na różny poziom kreatywności w pracy jest możliwe. Istotne znaczenie będzie tu miało adekwatne dla danej organizacji zdefiniowanie kreatywności, a następnie przyjęcie odpowiedniej skali. Na podstawie tak przygotowanego opisu kompetencji można wyznaczać określony poziom wymagań kreatywności dla danego stanowiska, oceniać poziom kompetencji kandydata na podstawie przygotowanych zadań $w$ ramach assessment center ${ }^{1}$ oraz oceniać zmiany poziomu kompetencji u pracowników w trakcie ocen okresowych. 


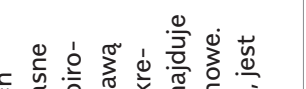

d $\stackrel{1}{3} \frac{1}{+0}$

1

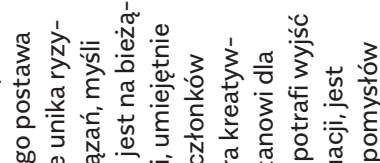

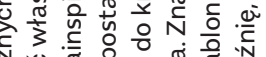

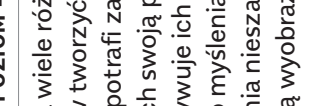

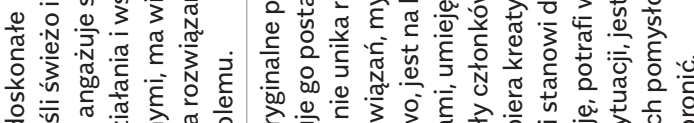

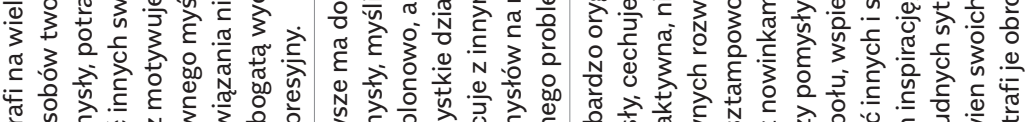

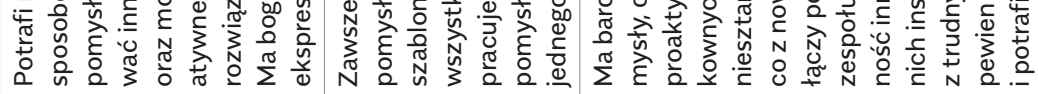

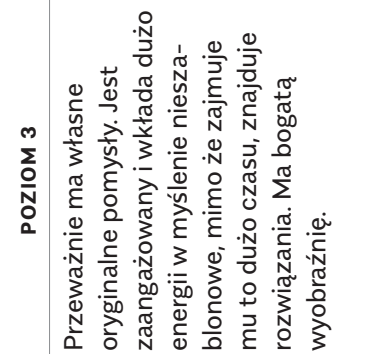

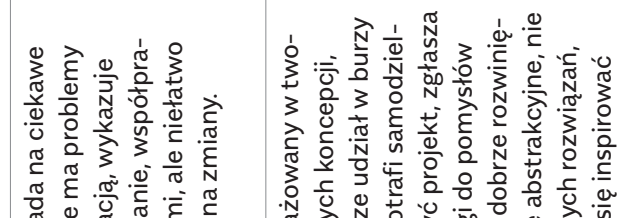

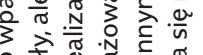

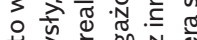

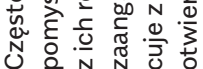

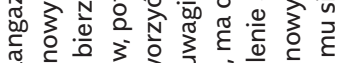

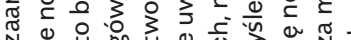

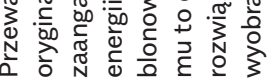

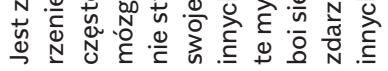

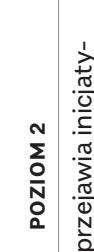

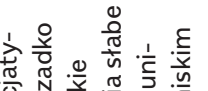

N

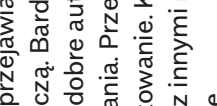

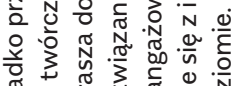

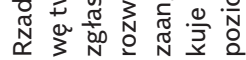

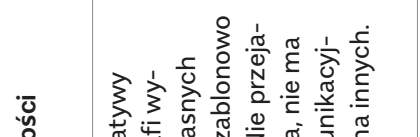

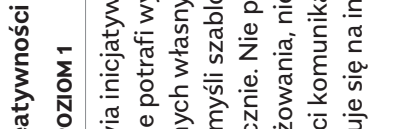

辛

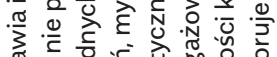

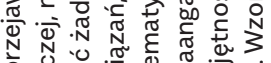

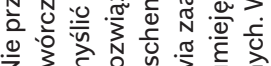

음

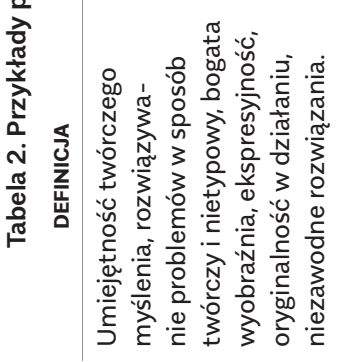

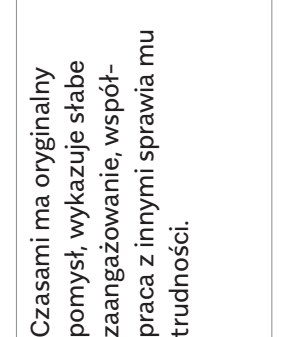

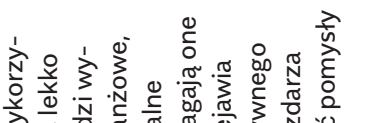

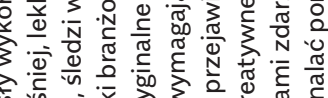

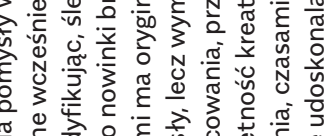

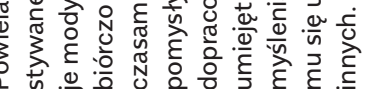

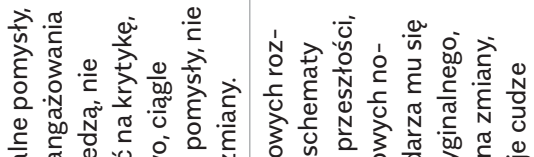

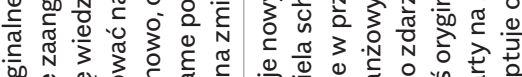

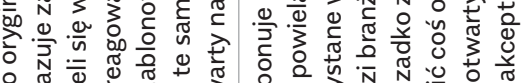

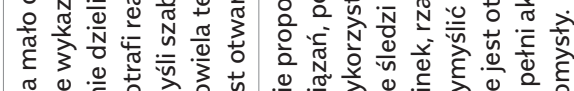

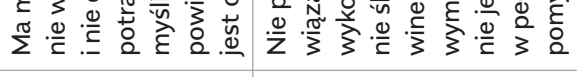

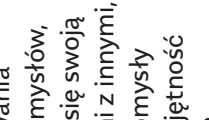

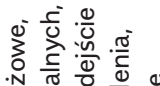


Zatem na pierwsze z postawionych pytań: „Czy pracodawcy posiadają narzędzia do oceny kreatywności?", można odpowiedzieć twierdząco. Nie przedstawiono konkretnych przykładów pochodzących z praktyki gospodarczej, ale wykazano, że dla pracodawcy wykorzystującego w zarządzaniu podejście oparte na kompetencjach zdefiniowanie i zwymiarowanie tej kompetencji jest możliwe. Wątpliwość może budzić jedynie stopień upowszechnienia w praktyce zarządzania kompetencjami. Jak wynika z badań przeprowadzonych w Polsce w 2013 r. na próbie 941 przedsiębiorstw, prawie połowa z nich (47,6\%) już wprowadziła profile kompetencyjne, a kolejnych $15 \%$ było $w$ trakcie ich wdrażania. Jednak $18,3 \%$ badanych firm nie planowało wdrożenia profili kompetencyjnych (Sienkiewicz 2013, s. 53).

Drugim analizowanym zagadnieniem jest to, czy wymóg kreatywności od kandydatów jest adekwatny do charakteru realizowanych zadań? Dane z tabeli 2 wskazują, że we wszystkich opisach przewidziano sytuację, w której pracownik nie przejawia zachowania kreatywnego $\mathrm{w}_{\text {pracy }}^{2}$. Wynika to z przeświadczenia, że istnieje sporo stanowisk pracy, na których wymaga się precyzyjnego przestrzegania norm postępowania i podporządkowania się przyjętym zasadom, a wszelkie odstępstwa od ustalonej procedury byłyby szkodliwe lub wręcz niebezpieczne - są to stanowiska niewymagające kreatywności lub na których kreatywność może być wręcz przeszkodą. Można tu przywołać chociażby przykłady niektórych stanowisk laboratoryjnych, medycznych, urzędniczych czy wykonawczych zaangażowanych w procesach produkcyjnych lub usługowych. Nie chcielibyśmy, aby nasz samochód był składany przez mechanika mającego kreatywne podejście do montowania kolejnych elementów. Wolimy, aby ściśle przestrzegał on wszelkich procedur. Nie zmienia to jednak faktu, że oczekujemy, by projektanci samochodów byli pracownikami bardzo kreatywnymi w zakresie aspektów zarówno technicznych, jak i dotyczących designu tworzonych produktów. Na niektórych stanowiskach zdecydowanie większą wagę przywiązuje się do znajomości metod pracy, określanych fachowością, która będzie przejawiać się w skru-

$2 \quad$ Nie oznacza to automatycznie, że osoba taka nie jest kreatywna. Być może jej kreatywność dotyczy innych obszarów życia, poza pracą. Może też wskazywać, w określonych sytuacjach, że pracownik nie jest świadom określonych oczekiwań względem niego. Często jednak wskazuje na określoną postawę pracownika, która wynika z jego predyspozycji i możliwości. 
pulatności, dokładności, precyzji, niezawodności działania. Podobny pogląd prezentował Tadeusz Oleksyn, powołując się na Petera Druckera, który twierdził, że nie należy stawiać celów innowacyjnych przed pracownikami: odpowiedzialnymi za utrzymanie ruchu, eksploatację i optymalizację istniejących procesów. Twierdził, że nie wszyscy pracownicy muszą być "rozwojowi”, gdyż w organizacji potrzebne są różne typy pracowników, w tym także "konie pociągowe" (Oleksyn 2006, s. 60). Warto również odwołać się do opinii 135 menedżerów uczestniczących w projekcie badawczym, spośród których tylko $45 \%$ uznało kreatywność za bardzo potrzebną, a 33,6\% za potrzebną w pracy. Co ciekawe, przydatność kreatywności została najwyżej oceniona przez menedżerów polskich, a najniżej przez przedsiębiorców fińskich. Jak stwierdza Waldemar Jędrzejczyk (2017), badanie wykazało, że im wyższy poziom kreatywności kraju, tym niżej oceniono przydatność kreatywności jako kompetencji zawodowej.

Dlaczego więc pracodawcy coraz częściej oczekują od pracowników kreatywności? Można przyjąć, że stanowiska pracy różnią się charakterem zadań i że niektóre $z$ nich wymagają sprawnego rutynowego wykonywania obowiązków. Pojawia się jednak także kwestia sytuacji nietypowych, nadzwyczajnych. W obecnych czasach zdarzają się one coraz częściej i wymagają działań niestandardowych, znajdowania nisz popytowych, tworzenia nowych propozycji dóbr i usług. Nasuwa się wobec tego pytanie, czy pracodawcy, formułując wymóg kreatywności wobec kandydatów do pracy, zawsze rzeczywiście mają na myśli kreatywność. Być może kreatywność jest przez nich rozumiana jako postawa przeciwstawna bierności i bezradności. Wobec tego być może w istocie bardziej zależy im na przedsiębiorczej postawie pracownika, który podejmuje działania, kierując się interesem organizacji i realizacją jej celów, ale niekoniecznie musi być w tym kreatywny. Jakoś trudno wyobrazić sobie życie w otoczeniu osób zawsze kreatywnych, natomiast oczekujemy, że nie będą nas otaczać ludzie bezradni i bierni. To jednak nie to samo co wymóg, aby wszyscy byli kreatywni.

Inną kwestią związaną z rosnącą popularnością wymogu kreatywności jest wzrost znaczenia usług wykorzystujących wiedzę pracowników, tzw. usług wiedzochłonnych. To właśnie tego rodzaju przedsiębiorstwa w szczególny sposób eksponują znaczenie kreatywności jako wymaganej kompetencji zawodowej. O ile w przywoływanych już badaniach na próbie 941 firm średnio $26 \%$ badanych wskazywało na 
kreatywność jako kompetencję wymaganą od kandydatów do pracy, o tyle w przypadku firm dostarczających usługi wiedzochłonne było to $33 \%$ (Sienkiewicz 2013, s. 69).

\section{Podsumowanie}

Kreatywność jest obecnie zachowaniem bardzo pożądanym w różnych sytuacjach życiowych. Cenią ją zwłaszcza pracodawcy oczekujący, że pracownicy w momentach nietypowych wykażą się inicjatywą i zaproponują nowe rozwiązanie problemu. Jednocześnie formułowane są liczne opinie krytyczne o tym, że szkoła nie kształtuje w wystarczającym stopniu kreatywnej i innowacyjnej postawy u uczniów. Celem artykułu była krytyczna refleksja nad zasadnością powszechnego wymogu kreatywności formułowanego pod adresem nauczycieli i szkół, a także kandydatów do pracy i pracowników.

Krótki przegląd sposobów ujmowania kreatywności w literaturze pozwolił na przyjęcie takiej definicji kreatywności, która opierała się na zachowaniu. Ma to istotne znaczenie dla pomiaru kreatywności wykorzystującego podejście kompetencyjne, które jest szczególnie przydatne w warunkach przedsiębiorstwa. Dzięki temu możliwe było udzielenie odpowiedzi na jedno z postawionych w tekście pytań: „Czy pracodawcy dysponują narzędziami do oceny kreatywności pracowników?". Wykorzystana przy tej okazji kreatywność studentów, którzy przygotowują się do pracy w działach zarządzania zasobami ludzkimi, dowiodła, że możliwe jest zdefiniowanie i zwymiarowanie kompetencji kreatywności na potrzeby konkretnej organizacji. Rezultaty ćwiczenia przeprowadzanego w warunkach zajęć, w oderwaniu od prawdziwego kontekstu organizacyjnego, nie są w pełni satysfakcjonujące, ale wskazują, że fachowcy są w stanie przygotować dla organizacji narzędzie diagnozujące kreatywność. Przytoczone wyniki badań w przedsiębiorstwach w Polsce potwierdziły, że większość badanych wdrożyła lub wdraża profile kompetencyjne do zarządzania, z czego $26 \%$ wymaga kreatywności od zatrudnionych pracowników.

Na postawione w tytule pytanie: „Czy wszyscy muszą być kreatywni?" można sformułować następującą odpowiedź: nie wszyscy muszą być $w$ tym samym stopniu kreatywni, ale w szkole powinno dążyć się do rozwijania kreatywności u każdego ucznia. Natomiast nie wszystkie stanowiska pracy wymagają od pracowników kreatywności, wobec czego powszechność tego wymogu wobec pracowników jest nieco na 
wyrost. Zmienia się natomiast struktura przedsiębiorstw i głównie w firmach świadczących usługi, w tym tzw. usługi wiedzochłonne, będzie wzrastać znaczenie kreatywności.

Kreatywność rozwinięta w szkole może być wykorzystywana w różnych innych aspektach życia we współczesnym świecie. Dlatego szkolnictwo wymaga zmian programowych polegających nie na poszerzaniu, ale zredukowaniu treści oraz systemowych zmian organizacyjnych, aby stworzyć nauczycielom lepsze warunki do redukowania poznawczych i emocjonalno-motywacyjnych barier kreatywności uczniów. Dużą rolę może tu odegrać rozwijanie dywergencyjnego myślenia i stylu uczenia się u uczniów. W odniesieniu do pracodawców można stwierdzić, że profesjonalizacja procesów personalnych w organizacjach, w tym oparcie ich na podejściu kompetencyjnym i stworzeniu profili kompetencyjnych stanowisk pracy, może stanowić ważny krok w urealnieniu wymagań wobec kandydatów do pracy oraz może sprzyjać bardziej sprawiedliwej ocenie stopnia dopasowania kompetencji pracownika do wymagań jego stanowiska pracy. Tym samym przyczyni się to do lepszego wykorzystania potencjału pracowników oraz udoskonalenia procesów planowania ich dalszego rozwoju. 